those of an independent African survey by Harding ${ }^{3}$ (see ref. (1)). The results of this survey indicate that any non-linearity is probably due to error in the Harding values.

Further results from this survey will be published at a later date.

George H. Sutton

Institut pour la Recherche

Scientifique on Afrique Centrale,

Centre de Recherche du Kivu,

Lwiro (Bukavu), Congo Belge. March 26.

'Duclaux, F., Martin, J., Blot, C., and Remiot, R., "Etablissement d'un Reseau Général de Stations Gravimétriques en Afrique, à Madagascar, à La Réunion et à l'Ile Maurice" (Office de la Recherche Scientifique et Technique Outre-Mer, Paris, 1954).

'Herrinck, P., Nature, 172. 258 (1953).

' Woollard, G., Harding, N., Muckenfuss, C., Bonini, W., and Black, W., Woods Hole Oceano. Inst., Tech. Rep. 52-59, July 1952 (unpublished manuscript).

\section{Effect of Rainstorms upon the Cotton Jassid in the Sudan Gezira}

Empoasca lybica de Berg., a pest of cotton in the Sudan Gezira Scheme, invades the seedling crop early in September, the infestation normally reaching its maximum intensity in the last half of November. Hanna ${ }^{1}$ records that peak populations of this insect are affected by rainstorms of $10 \mathrm{~mm}$. and more in July and August as well as by dust storms in September. Field observations by Cowland and Hanna ${ }^{2}$ suggest that populations upon cotton are also affected by rainstorms in September. Rainstorms, probably because of the mud which splashes on to the lower leaves, reduce the number of jassids infesting the cotton. Those findings which concerned the direct effect of rainstorms upon jassids at nine sites in the northern part of the Sudan Gezira were not reported by Hanna ${ }^{1}$ in his published paper on rainfall and jassid numbers.

The late rains of September-October 1955 furnished three occasions on which to investigate the effects of rainstorms directly upon jassids infesting standing cotton.

A rainstorm of $10.6 \mathrm{~mm}$. occurred during the afternoon of September 25, 1955, at the Gezira Research Farm. That morning, because of the hot humid weather associated with an approaching storm, counts of jassids in an observation plot (laid out for another purpose) had to be abandoned after two subplots had been examined. Next day, counts on remaining subplots were completed. The mean number of jassid nymphs per plant in the six sub. plots of the experiment are shown in Table 1.

On September 26 there were in all cases fewer jassids on the plants than on September 21, although from the incomplete count on September 25 the mean population per plant had increased during the previous four days. The figures from subplot II clearly show how the increase of population is followed

Table 1. Mean Numbers of Jassids PER Plant

\begin{tabular}{|c|c|c|c|c|c|c|}
\hline \multirow{2}{*}{$\begin{array}{c}\text { Da te of } \\
\text { count }\end{array}$} & \multicolumn{6}{|c|}{ Subplot } \\
\hline & I & II & III & IV & V & VI \\
\hline $\begin{array}{l}21.9 .55 \\
25.9 .55\end{array}$ & 0.37 & $0 \cdot 18$ & $0 \cdot 29$ & 0.16 & 0.26 & $0 \cdot 16$ \\
\hline $\begin{array}{l}25.9 .55 \\
26.9 .55\end{array}$ & $\stackrel{0.61}{-}$ & $\begin{array}{l}0.43 \\
0.14\end{array}$ & $0 \cdot 18$ & $\begin{array}{r}\mathrm{sesuh} \\
0 \cdot 03\end{array}$ & $\begin{array}{l}\text { s aba } \\
0.17\end{array}$ & $0 \cdot 12$ \\
\hline
\end{tabular}
Table 2. Changes of Jassid PopUlations Associated with 4

\begin{tabular}{|c|c|c|c|c|c|c|}
\hline \multirow{2}{*}{ Zone } & \multirow{2}{*}{$\begin{array}{l}\text { Repli- } \\
\text { cates }\end{array}$} & \multicolumn{3}{|c|}{ Jassids/100 leaves } & \multicolumn{2}{|c|}{$\begin{array}{c}\text { Rainfall } \\
\text { (weekly periods) }\end{array}$} \\
\hline & & Sept. 23 & Sept. 30 & Oct. 8 & $\begin{array}{c}\text { Sept. } 23 \\
\text { to } \\
\text { Sept. } 30\end{array}$ & $\begin{array}{c}\text { Sept. } 30 \\
\text { to } \\
\text { Oct. } 8\end{array}$ \\
\hline $\begin{array}{l}\text { Within } \\
\text { storm } \\
\text { area } \\
\text { Beyond } \\
\text { storm } \\
\text { area }\end{array}$ & 13 & $19 \cdot 6$ & $23 \cdot 4$ & $17 \cdot 2$ & $20 \mathrm{~mm}$. & $\mathrm{Nil}$ \\
\hline
\end{tabular}

by fall in numbers after the rainstorm on September 25.

Counts were made on October 2 and 4 of the number of jassid nymphs per 100 leaves at random in each subplot of a five-feddan field (about $5 \cdot 2$ acres). The field was divided longitudinally into three equal strips and each strip contained 20 subplots. During the afternoon of October $3,9 \cdot 3 \mathrm{~mm}$. of rain fell upon this field at the Gezira Research Farm.

There were thus sixty pairs of 'before and after' rain counts of jassids in the same subplots. The mean decrease of population of $20 \cdot 0$ to 12.8 jassids per subplot was significant at 1 per cent level. There was, however, no significant difference between the twenty pairs of counts in the middle strip, although the pairs of counts in the subplots along the east and west edges of the field were significantly different at 1 and $0 \cdot 1$ per cent levels respectively.

A particularly striking example of the check of jassid numbers associated with a rainstorm in a roughly triangular area of about 300 square miles in the northern Gezira occurred on September 26, 1955. Within that area rain-gauges registered between 16 and $29 \mathrm{~mm}$. of rain; outside the area gauges showed a 'trace' to $5 \mathrm{~mm}$.; this was the last storm of the season in that area. Table 2 shows the relevant jassid count per 100 leaves.

Between the 'before and after' rain counts inside the storm area, the observed mean fall of population is significant at 1 per cent level, while beyond the storm zone the increase of population in the same period, September $23-30$, is significant at the 1 per cent level. Inside the storm area, all counts on September 30 were less than the corresponding count on September 23; but outside the storm zone the exact reverse was true.

A map showing the locality of the sampling areas and rain gauges has been deposited at the British Museum (Natural History), South Kensington.

While the checks to breeding associated with rainstorms tend to delay the build-up of jassid population on cotton, observation at the end of November, the time of peak populations, showed no marked differences in the number of insects on the cotton within and beyond the storm area of September 26.

We wish to thank the Chief of the Research Division and the General Manager of the Sudan Gezira Board for permission to publish this communication.

\section{Gezira Research Farm,}

Atan Goodman

Wad Medani.

\section{A. M. Toms}

Sudan Gezira Board Headquarters, Barakat, Sudan.

\footnotetext{
1 Hanna, D., Bull. Ent. Res., 41 (2), 339 (1950).

a Cowland, J. W., and Hanna, A. D., Ann. Rep. Res. Div, Min. Agric.
} Sudan Govt., $1948 / 49$, p. 106 (1951) 